\title{
LA GUERRA DE LA INDEPENDENCIA EN EL IMAGINARIO COLECTIVO ESPAÑOL: DOS SIGLOS DE MEMORIA ORAL
}

La guerra de la Independencia que libraron los españoles (la que libraron los portugueses queda fuera ahora de nuestros alcances) contra los franceses, hace ahora justo dos siglos, dejó una impronta muy duradera no sólo en la historia oficial, es decir, en la crónica con mayúsculas, con nombres y con apellidos, de revueltas y batallas, generales y rebeldes, ofensas y defensas, grandes nombres y destacadas efemérides. También en la vida cotidiana de entonces, en la memoria oral transmitida de una generación de españoles a la siguiente, en el imaginario colectivo en definitiva, quedaron prendidos -durante décadas primero, durante siglos después- recuerdos que fueron haciéndose cada vez más tibios, más distorsionados, más nebulosos, pero que, al cabo del tiempo, siguen funcionando como hilos dramáticos, emotivos, orgullosamente exhibidos, del entramado de la identidad nacional española.

No podía ser menos: pocos acontecimientos como la guerra de la Independencia tuvieron un impacto tan directo y tan brutal en la vida y en la historia de cada pueblo, de cada familia, de cada persona que la sufrió - tanto como sobre la historia grande del país-, y muy pocas -o acaso ninguna- de las grandes conmociones históricas que ha sufrido España desde la Reconquista quedaron resueltas de un modo tan positivo para los intereses españoles -según, al menos, la opinión que más ha trascendido-, ni contribuyeron de forma tan poderosa -ni tan cuestionable, como apuntaremos- a la articulación de un imaginario nacionalista, heroico, exultante, catártico, que no ha dejado de alimentar las emociones patrias desde entonces hasta hoy.

Hay dos formas de entender la guerra de la Independencia: encerrada en sí misma, sin atender a los tristes acontecimien- 
tos que se sucedieron antes ni, sobre todo, a los que vinieron después; o considerándola un eslabón más, aunque sincopado, refulgente, dramático, del continuum de una historia larga y trágica que, si bien se mira, no da para tantos entusiasmos, ni patrios ni de ninguna otra especie.

La primera forma se corresponde con la vulgata épica que me contaron a mí y a muchísimos otros cuando éramos niños y cuando éramos jóvenes, en la escuela o frente al televisor; es decir, con la versión privilegiada en las épocas de mayor exacerbación patriótica, con la interpretación heroica que asume, sin mayores complicaciones, la mayoría de los españoles que carecen de una formación especializada ni crítica en el terreno de la historia. A la segunda forma, más relativista, pesimista, escéptica, se llega a poco que se pregunte uno por el antes y por el después, que se profundice en los libros de historia, que se hagan ciertas reflexiones al margen de prejuicios y, sobre todo, a salvo -si es que eso es posible- de la propaganda nacionalista que ha convertido en una guerra gloriosamente épica lo que fue, más bien, un episodio especialmente dramático dentro de un período convulso y desdichado, y con un desenlace absolutamente decepcionante, de nuestra historia.

Si aislamos la guerra de 1808-1814 de los trágicos acontecimientos que vinieron inmediatamente después (la represión de las aspiraciones democráticas de las clases medias y bajas que cargaron con el peso de la rebelión, el recrudecimiento de la dictadura absolutista, la nueva y victoriosa invasión francesa de 1823), es verdad que la guerra de la Independencia podría tener ciertos visos de victoria militar, social, cultural, y, sobre todo, moral. Acaso la única destacada de nuestro país desde la Edad Media.

Porque las gestas de la unificación, de la conquista de América, del gran Imperio carolino y filipino, que inauguraron nuestra Edad Moderna, no dejaron un expediente tan limpio ni tuvieron un impacto tan duradero en el imaginario ni en la conciencia colectiva de los españoles -salvo en las épocas de más ciega e indiscriminada exaltación nacionalista. Primero, porque la agónica decadencia imperial, la anexión y la posterior pérdida de Portugal, las rebeliones e independencias americanas, fueron convirtiendo, en un goteo que llegó a hacerse rutinario, los resonantes triunfos del siglo XVI en amargas derrotas. Y, además, porque la factura de la unificación, de la expansión colonial, del Imperio, fue en buena medida pagada con la 
moneda de la expulsión, la persecución, la conversión forzosa, el silenciamiento, el sometimiento militar y político, la pérdida de los derechos civiles, la esclavitud, la tortura, la muerte de millones de musulmanes, judíos, gitanos, indios, negros, protestantes y demás gentes - civiles indefensos en su inmensa mayoría- cuyo delito fue ser, simplemente, lo que eran (es decir, musulmanes, judíos, indios, etc.), con los agravantes, a juicio de los adalides de la civilización y redentores de almas que los juzgaron culpables, de paganos, infieles, herejes, salvajes, atrasados, fanáticos, supersticiosos y facciosos.

La guerra de la Independencia tuvo, por lo menos, el mérito de ser una guerra defensiva y no ofensiva. Ello fue lo que, en esencia, le dio una legitimidad moral indiscutible. Ahora bien: el que fuera una guerra victoriosa en contra de los franceses y en favor de la libertad (o de las libertades) de los españoles es una verdad sólo a medias, o quizás menos que a medias: la revancha que se tomaron los Cien Mil Hijos de San Luis al invadir (y aplastar) España muy poco tiempo después, en 1823, obliga a interpretar esa victoria española contra Francia como una batalla en mitad de una guerra perdida. Y el mito del pueblo en armas, descamisado, despeinado, insumiso -réplica fiel del pueblo levantado (y enseguida traicionado, por supuesto) de la Revolución Francesa-, que se liberó a sí mismo, y por sí solo, del yugo opresor, precisa también, sin duda, de alguna puntualización, puesto que la decisiva intervención inglesa y los manejos poco visibles de las diplomacias europeas que no dejaron de mover ciertos hilos de lo que sucedió obligan, también, a interpretar aquella revuelta popular, y su carácter supuestamente espontáneo, incontenible, decisivo, con muchísimos matices.

Máxime si se tiene en cuenta cómo acabó tan refulgente y democrática explosión de entusiasmo rebelde: en el ingreso al oscuro redil del siniestro dictador Fernando VII, que se las arregló para encauzar y confiscar a favor suyo toda la energía -tan brillante como efímera- liberada por unos ciudadanos, fundamentalmente, de clase burguesa y baja -en realidad, por las clases que estaban por debajo de la nobleza-, cuya ingenua falta de previsión y de estrategia política convirtió en pólvora mojada, desactivada y traicionada (por el mismo rey y por la misma aristocracia por los que sacaron pecho) los sacrificios, dolores y riesgos que ellos en exclusiva afrontaron.

Por fortuna, muchas tornas, hoy, han cambiado, y las lecturas flamígeras y las fantasías groseramente nacionalistas sobre 
la francesada que yo y muchos más tuvimos que asimilar como dogmas de fe cuando éramos niños y jóvenes han visto bastante reducido su margen de acción y propagación, y encuentran hoy enfrente, por ejemplo, generaciones de maestros más preparados y menos ideologizados, y una representación muy valiosa y sustancial de la historiografía contemporánea, encarnada en títulos atrevidamente renovadores -aunque no exentos de puntos polémicos- como Mater dolorosa: la idea de España en el siglo XIX (2001), de José Álvarez Junco, La maldita guerra de España. Historia social de la guerra de la Independencia, 18081814 (2006), de Ronald Fraser, o El sueño de la nación indomable: los mitos de la guerra de la Independencia (2007), de Ricardo García Cárcel ${ }^{1}$-y unos cuantos más-, que han logrado romper con la historiografía patriotera y con las proclamas etnicistas del pasado, instalar la siempre sana duda metódica -en vez de la convicción metódica de antes- en el centro de sus reflexiones, y situar la discusión en el terreno de las ciencias positivas. Hasta el título de guerra de la Independencia-entre muchísimos más dogmas- ha sido muy razonablemente cuestionado en estas últimas hornadas de historiografía tan necesarias, tan depurativas, tan iluminadoras.

La escuela patriótica, las lecturas obligatorias, las soflamas de los maestros a los que les habían metido en la cabeza la misma historia, fueron -ya lo he apuntado- la cocina en la que fue preparada la versión románticamente nacionalista de la francesada. Los relatos que a la gran mayoría de los españoles -sobre todo a los de mi generación y a los de las anteriores- nos contaron cuando éramos niños y adolescentes nuestros maestros de escuela, nuestros profesores de instituto, o los formadores del espiritu nacional, ponían todo el énfasis, desde luego, sobre los aspectos más positivos, más épicos, más entusiastamente patrióticos, de la emotiva gesta nacional. Eso explica que, en la escuela franquista en la que yo me eduqué hasta que tuve diez años, las intervenciones en suelo español de los ingleses, o la brutal revancha de los Cien Mil Hijos de San Luis, no tuvieran ninguna presencia, o que aparecieran como nota muy al margen dentro del guión que debíamos memorizar. ¿A quién se le iba a ocurrir conceder a los ingleses porción alguna, por pequeña que fuera, del pastel de la victoria del indómito pueblo español?

1 Mater dolorosa..., Taurus, Madrid, 2001; La maldita guerra..., Crítica, Barcelona, 2006; El sueño de la nación..., Temas de Hoy, Madrid, 2007. 
Y ¿quién iba a aceptar que los franceses acabarían humillando la cerviz, tan pronto, en 1823, de los patriotas españoles supuestamente invictos que les plantaron cara entre 1808 y 1814? ¿Cómo conciliar tales detalles con los laureles de ingobernables y de invencibles con que los coronaban nuestros libros de la escuela y los discursos patrióticos que escuchábamos?

Agustina de Aragón -figura absolutamente secundaria y anecdótica de la historia de nuestro país- nos era insistentemente presentada como la tercera persona de la santísima trinidad femenina, providencial y redentora de los destinos de España que encabezaban la virgen del Pilar e Isabel la Católica. Y los acentos atronadores de la oda El dos de mayo de Bernardo López García lo mismo eran difundidos a ritmo marcial por la radio (de la que la aprendieron y memorizaron innumerables personas, incluso iletradas, como yo mismo he podido comprobar en mis encuestas de campo por toda España) que eran tema de dictado o de memorización obligatoria en las escuelas:

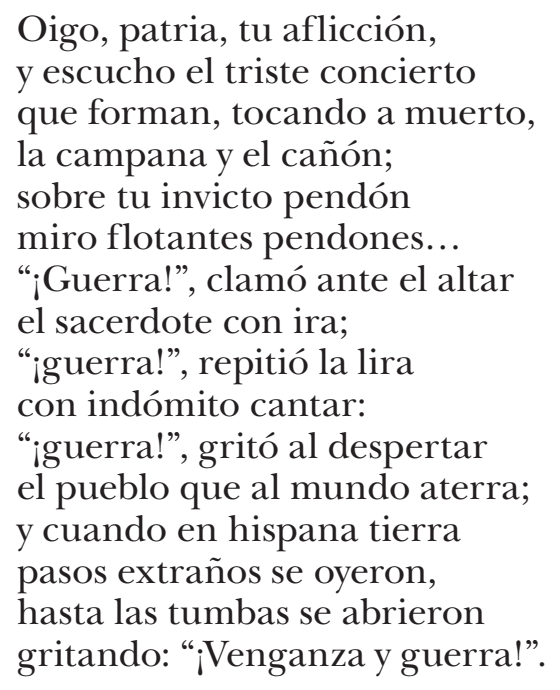

En definitiva: la imagen más común que de la guerra de la Independencia ha guardado la retina popular, la conciencia colectiva de muchísimos españoles con conocimientos históricos no especializados, la que nos contaron y nos volvieron a contar tantas veces como dogma de fe, es una versión vulgata, de consumo interno, tan heroica y optimista como superficial, mutilada y distorsionada, de unos hechos que distaron mucho de desarrollarse al son de una música tan brillante. Un mito 
tan desenfocado y falaz como suelen serlo todos los mitos elaborados y blandidos por cualquier nacionalismo. Un capítulo de tragedia, sólo efímeramente épico, que tuvo un trasfondo político, unas proyecciones estratégicas, unas consecuencias históricas, bien diferentes, y no, desde luego, tan positivas ni tan rutilantes como las que los altavoces de las emociones patrias han divulgado.

La historia de la francesada es, si se ve con un mínimo de perspectiva histórica, la historia de una revuelta popular y ciudadana que fue, al final, traicionada y derrotada por quienes se las arreglaron para subirse a su ola, controlar su energía y percibir sus réditos: la realeza y la aristocracia. Mientras el pueblo se desangraba en las calles gritando con fervor el nombre de su rey, al que llamaron, torpemente, el Deseado, éste no dejó en ningún momento de tramar el aplastamiento de ese mismo pueblo, acción que fue perpetrada en cuanto hubo ocasión. El saldo de la guerra de la Independencia, para las clases medias y bajas que del modo más voluntarioso la cargaron sobre sus espaldas, no pudo ser más desolador: los muertos los pusieron ellos, los gastos los pagaron ellos, y la situación de pérdida de derechos y de libertades con que se cerró fue, sin comparación, más grave que la que se sufría antes de la invasión napoleónica.

¿Algo que ver con la fábula optimista y con los brillantes efectos especiales que nos obligaban a retener en la escuela? Pues bien: del mismo modo que sobre la guerra civil española de un siglo y pico después han perdurado, durante décadas, un número incontable de recuerdos directos -mantenidos entre quienes la sufrieron, que fueron prácticamente todos los españoles de la época- o de evocaciones indirectas-vivas entre quienes escucharon la voz de quienes la sufrieron-, las guerras peninsulares contra Napoleón generaron un número inmenso de microrrelatos, de casos personales, de pequeñas anécdotas, que, a poco de nacer, o acaso desde los rescoldos mismos de los hechos, comenzaron a vestirse con los ropajes de la ficción, y a asentarse sobre el terreno difuso y movedizo que marca la línea divisoria -o, mejor dicho, el espacio de transición- entre la realidad y la imaginación, entre lo que se vivió entonces y lo que fue contado más tarde.

Ronald Fraser, en La maldita guerra de España, uno de los libros más hermosos, más originales y más difíciles de los que se hayan escrito nunca sobre la historia de España, ha logrado la proeza de recuperar muchas voces que vivieron y que contaron 
en primera persona -o en personas en todo caso muy próximaslo que les sucedió a ellos o a los suyos en aquellos días convulsos.

Este artículo mío va a intentar seguir, modestamente, ciertas vías abiertas por Fraser, y tomar el pulso de algunos de esos relatos de guerra que, dispersos, atomizados, deshilvanados, han mantenido un hilo de voz gracias a que algunas personas han seguido recibiendo hasta hoy, por herencia oral de sus mayores -no de la propaganda nacionalista ni de las pintorescas lecciones de historia de la escuela de antes-, los ecos cada vez menos audibles del fragor de la francesada. Algunos han quedado consignados, también, entre los pliegues recónditos de una bibliografía más o menos etnográfica, muy heterogénea y desigual, de leyendas y de cuentos entre los que, si se espiga mucho y con ojos muy escrutadores, asoma de vez en cuando algún relato evocador de aquellos tiempos y de aquellos hechos.

Es a esta francesada oral, alternativa, no canónica, menos conocida, refugiada en recuerdos personales, familiares, privados, en páginas de libros locales, de folclor, de tirada corta y circulación modesta, a la que voy a prestar más atención en este trabajo.

No será fácil, en cualquier caso, obviar la influencia de los relatos sobre la francesada más ideologizados, más edulcorados, más propagados e institucionalizados, aquellos que los acuñadores del nacionalismo español elevaron a la condición de sagrados e indiscutibles mitos patrios. De hecho, muchos de los versos y de las prosas que voy a traer a colación pulsan esa cuerda heroica. Pero tienen la singularidad, al menos, de estar escritos con la letra pequeña de esas tradiciones orales, anónimas y locales, que aunque no hayan permanecido inmunes a la influencia de la propaganda nacionalista, han conservado, hasta hoy, ciertos rasgos de espontaneidad y de frescura, trazas de ser versiones en cierto modo intrahistóricas, que las convierten en piezas breves pero no menores del mapa de los hechos que quedó dibujado en el imaginario colectivo español.

Convendrá, en cualquier caso, que nos asomemos a todos estos documentos con la sana ironía y con el agudo descreimiento con que Francisco Márquez Villanueva se refirió a la sombra -tan larga como hinchada- que la francesada dejó en el recuerdo de su propia infancia sevillana:

Un profesional curtido en los estudios históricos experimenta vivo placer al tropezar con el pálpito del pasado en el testimonio de 
la traducción oral, en cuanto eco diferido, pero más que nunca veraz, de una experiencia colectiva. Así, por ejemplo, los beduinos del desierto de Sinaí informan con orgullo y casi piedra por piedra acerca de las tradiciones bíblicas de la tierra, y en este caso hasta reinventadas, porque sus antecesores no se establecieron en ella hasta el siglo viI. Su protagonista favorito ha de ser, por supuesto, Moisés: "Por allí se acercó Moisés...”, “...junto a estas piedras encontró a la que iba a ser su esposa...”. Todo adornado con escolios de propia cosecha, pero sin duda eminentemente plausibles: "Como en aquella época no había mapas y Moisés no era de aquí, pues ocurrió que anduvo perdido, dando vueltas con toda su gente por cuarenta años".

En mi propia niñez tuve ocasión de escuchar de boca de un anciano del barrio sevillano de San Bernardo (el muy popular de los toreros), alejado en dos o a lo más tres generaciones, las tradiciones de la ocupación napoleónica y no por cierto en calidad de oídas ni de testigo, sino hasta de protagonista: "Cuando un francés se adentraba por el barrio, lo agarrábamos entre tres o cuatro y lo tirábamos a un pozo”. No había ninguno en San Bernardo que no tuviera en su fondo media docena de franceses ${ }^{2}$.

Aunque nos centraremos sobre todo en los ecos que la francesada dejó en el imaginario colectivo de hoy, o de las décadas más recientes, es inevitable hacer un poco de historia y traer a colación unos cuantos textos del siglo xix que ponen en nuestras manos el hilo conductor entre lo que se contó cuando los hechos estaban todavía recientes y lo que se ha seguido contando un siglo y medio o dos siglos después.

Recordemos, en primer lugar, los dos párrafos que, con espíritu de incipiente etnógrafo y de observador desprejuiciado de la realidad -por su condición de extranjero, seguramente-, insertó el escritor y viajero norteamericano Washington Irving en sus Cuentos de La Alhambra de 1832. Porque muestran la cara -épica- y la cruz -escéptica- de (la percepción de) los hechos:

Más entrada la noche se aumentaron los personajes del drama. Un hombre como de sesenta años, de fornida y vigorosa naturaleza, entró impertérrito hacia adentro a charlar con mi posadera. Vestía el ordinario traje andaluz, pero llevaba un enorme sable debajo del brazo, con largos bigotes, y ostentaba un marcado aire de valentón. Parecía como que todos le miraban con gran respeto.

2 "Jamones de búfalo. El ayer y el hoy", El País, 13 de julio de 2004, p. 14 . 
Nuestro Sancho nos dijo en voz baja que era don Ventura Rodríguez, el héroe y campeón de Loja, famoso por sus proezas y por la fuerza de su brazo. En tiempos de la invasión francesa sorprendió a seis soldados que estaban dormidos: ató primeramente sus caballos, y después les acometió sable en mano, matando a uno y haciendo prisioneros a los demás. Por este hecho de armas le señaló el rey una peseta diaria y fue dignificado con el título de Don ${ }^{3}$.

Durante las últimas guerras habidas en España, mientras Granada se halló en poder de los franceses, la Alhambra estuvo guarnecida con sus tropas, y el general francés habitó provisionalmente en el Palacio. Con el ilustrado criterio que siempre ha distinguido a la nación francesa en sus conquistas, se preservó este monumento de elegancia y grandiosidad morisca de la inminente ruina que le amenazaba. Los tejados fueron reparados, los salones y las galerías protegidos de los temporales, los jardines cultivados, las cañerías restauradas, y se hicieron saltar en las fuentes vistosos juegos de aguas. España, por tanto, debe estar agradecida a sus invasores por haber conservado el más bello e interesante de sus históricos monumentos.

A la salida de los franceses volaron éstos algunas torres de la muralla exterior y dejaron las fortificaciones casi en ruinas. Desde este tiempo cesó la importancia militar de la fortaleza (ibid., p. 44).

Antonio Alcalá Galiano (1789-1865), político e intelectual liberal, masón, sañudamente perseguido por Fernando VII, exiliado, escribió al final de su vida (aunque no serían publicados hasta 1878) unos Recuerdos de un anciano que contienen jugosas anécdotas orales, y apuntes y matizaciones muy personales, acerca de la guerra del francés. Conozcamos alguna:

Siguieron cayendo en Cádiz granadas. Pero en mucho tiempo todas cuantas penetraron en la población se quedaron más cortas que la primera, y además viniendo como ésta llenas de plomo, y no reventando, dieron motivo a la famosa coplilla de

Con las bombas que tiran

los fanfarrones

se hacen las gaditanas

tirabuzones.

3 Ed. A. Gallego Morell, Espasa Calpe, Madrid, 1997, p. 41. 
Aclaraba el memorialista, en una interesantísima nota a pie de página, que se hacía en esta rima:

alusión a los rizos en forma de saca-corchos usados entonces, y que se formaban ciñendo con pedacitos de plomo delgadas mechas de pelo, que cubre y adorna la frente y las sienes.

D. Adolfo de Castro, en la obrilla excelente de su género, donde trae mil particularidades de lo ocurrido en Cádiz durante la guerra de la Independencia, cita esta coplilla, y con ella una variante que es como sigue:

Con las bombas que tira

el farsante de Soult

se hacen las gaditanas

toquillas de tul.

Pero como por fuerza ha de ver el lector, esto no tenía sentido, como lo de las tirabuzones. El Sr. de Castro (que no vivía entonces) ignora que esta variante tonta fue una copla improvisada y cantada en el teatro por un actor llamado Navarro que la echaba de gracioso, y a veces lo era, pero no a menudo. Al oírla fue aplaudida como suele serlo cualquier necedad, pero no era uso cantarla, pues bien se veía que no había materiales para medio pañuelo (vulgo toquilla en Andalucía) en las granadas que tiraban los franceses ${ }^{4}$.

De una generación posterior a la de Alcalá Galiano, Ramón de Mesonero Romanos publicó sus Memorias de un setentón, en 1881. Había nacido en 1803, y la guerra de la Independencia lo sorprendió, por tanto, en plena infancia. Pero entre lo que él vio de lejos y lo que le contaron los que lo vivieron de cerca, pudo dejar armados, muchas décadas después, unos recuerdos en los que se dejaba oír, sobre todo, el clarín patriótico:

Hombres y mujeres dirigían a los soldados franceses enconados apóstrofes o insultantes equívocos, animados por la seguridad de no ser comprendidos, y en toda la población surgieron, de improviso, canciones y tonadillas en loor de Fernando y de España. La más popular y primera en el orden de su aparición fue la que por su misma simplicidad llegó a verse reproducida hasta lo infinito desde Lavapiés hasta Maravillas y desde la puerta de la Vega hasta

4 Recuerdos de un anciano, Librería y Casa Editorial Hernando, Madrid, 1927, pp. 180-181. 
la de Alcalá. Esta dichosa cantinela, que no se caía de los labios de mujeres y niños, tenía por estribillo la ridícula muletilla de Juana y Manuela, en estos términos:

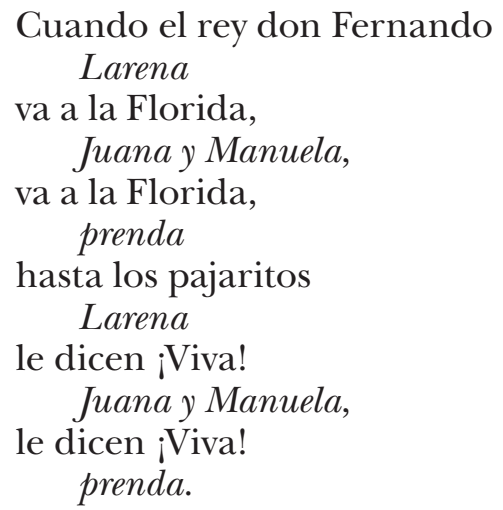

Con estas y otras coplas de inocente rusticidad, acompañadas con panderos y guitarras, con que ensordecían la población, procurábanse acercar todo lo posible a la antigua mansión del favorito, a la sazón del príncipe Murat (palacio contiguo a doña María de Aragón) acompañando esta algazara con entusiastas vivas a Fernando, a la Religión, a la España y a la Virgen de Atocha, todo con el piadoso objeto de mortificar en lo posible al enfadoso huésped, a quien por instinto cordialmente detestaban ${ }^{5}$.

Muchas más rimas populares, casos y anécdotas de primera, de segunda o de tercera mano dejó anotados Mesonero Romanos en sus memorias sobre la francesada, fuente esencial, desde luego, de cualquier acercamiento a la historia social, a la intrahistoria de aquellos acontecimientos.

Pero hay otras prosas del siglo XIX, y no sólo las declaradamente biográficas y autobiográficas -ni sólo las bien conocidas y difundidas de Galdós, que recibió de lleno la onda expansiva oral de aquellos acontecimientos-, en los que resuenan ecos de la guerra del francés que parecen relativamente etnográficos. Véanse, por ejemplo, estos párrafos del relato breve (novela de costumbres, lo tituló ella) La corruptora y la buena maestra, de Fernán Caballero (1796-1877):

5 Memorias de un setentón, natural y vecino de Madrid, eds. J. Escobar y J. Álvarez Barrientos, Castalia-Comunidad de Madrid, Madrid, 1994, pp. 113-114. 
-Señores, ¿me querrán ustedes decir por qué nombran a ese su compañero el tío Bumbum, que ese apodo me ha llamado la atención?

Yo se lo diré a su merced -repuso una vieja-. Años atrás, cuando volvió de la guerra del francés, trajo un cante que no se le caía de la boca, y éste tenía por remate el bum, bum de cañones. Tío Bumbum, bien podía usted cantárselo a la señora, ande usted.

El interpelado no se hizo de rogar y cantó en una bonita tonada, con voz fuerte, aunque cascada, esta antigua canción del tiempo de la Guerra de la Independencia:

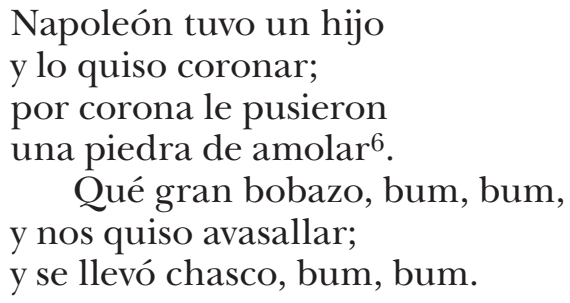

-Bum, bum -gritaron los muchachos, imitando tiros. torio.

-Otra, otra, que una no es ninguna -pidió riendo el audi-

-Pues vaya otra -respondió el anciano cantador:

$$
\begin{aligned}
& \text { Entró con alevosía } \\
& \text { que quiso a España, } \\
& \text { pero se salió de prisa, } \\
& \text { volviendo la cara atrás. } \\
& \quad \text { Qué gran bobazo, bum, bum, } \\
& \text { que quiso a España, } \\
& \text { y se llevó chasco, bum, bum. }
\end{aligned}
$$

La forastera, que estaba muy divertida, dijo entonces al veterano:

-¿Sabe usted cómo tienen ahora en Francia otro Napoleón?

El veterano contestó:

- ¿Y a mí qué se me da? A ver cómo no tienen veinte 7 .

Claro que quien desee conocer de manera más viva, precisa y cercana la tradición de canciones nacidas al calor directo de los hechos, tiene la fortuna de poder escuchar, ahora, el her-

6 Nota de la edición que sigo (cit. infra, n. 7): "El pueblo estuvo siempre en la creencia de que Napoleón había sido amolador".

7 La corruptora y la buena maestra, en Obras, ed. J.M. Castro Calvo, Atlas, Madrid, 1961, t. 4, pp. 425-426. 
moso registro de Canciones de la guerra de la Independencia, recopiladas por Federico Olmeda ${ }^{8}$, que ha grabado en 2003 un grupo de cantantes y de instrumentistas dirigidos por Joaquín Díaz, y que incluye tiranas, cachuchas, seguidillas y un interesantísimo muestrario adicional de canciones de agitación política y patriótica -a mitad de camino entre la música popular y la música de salón- que vieron la luz entre 1723 y 1823 :

Las composiciones que presentamos aquí se cantaron profusamente en aquellos tiempos, permanecieron en el acervo popular y algunas se siguieron cantando durante mucho tiempo. Las recogió el musicólogo Federico Olmeda de boca de un anciano que las oyó cantar en su juventud y constituyen una muestra muy representativa de aquellos avatares políticos, tal como los interpretó la musa popular. Fueron compuestas entre 1793 y 1823 aproximadamente y abarcan desde los últimos tiempos del reinado de Carlos IV hasta finales del Trienio liberal... Algunas nacieron en un lugar determinado y se extendieron luego por el resto de España; en Cádiz nacieron Marica, que trata del bombardeo de la ciudad por los franceses, el Trágala y el Himno de Riego, y no creo aventurado decir que también la Cachucha, por la mención del arsenal de la Carraca. Madrileñas serían Virgen de Atocha, Yo quería un cuarto para pan, tan triste, que aparecería tras la hambruna que padeció aquella capital en 1811 y 1812, y Juana y Manuela, por su mención de los paseos de Fernando VII en la Florida madrileña.

Son obras generalmente anónimas, nacidas de las circunstancias y de escaso valor literario; algunas utilizaron la música de canciones ya existentes o adaptaron las letras de otras. Están escritas en los metros cortos propios de la poesía popular, y predominan en ellas las seguidillas, que combinan versos de 7 y 5 sílabas y que, como las tiranas, eran el elemento principal de las tonadillas, y alcanzaron su máxima popularidad en el siglo XVIII. Las composiciones de carácter narrativo suelen ser romances o romancillos, y casi todas ellas llevan estribillo ${ }^{9}$.

8 El artículo en el que el músico y musicólogo castellano (nació en El Burgo de Osma, pero vivió casi toda su vida en Burgos) Federico Olmeda (1865-1909) dio a conocer las canciones sobre la francesada, que recogió de viva voz de un anciano de extraordinaria memoria, se tituló "Guerra de la Independencia”, y fue publicado en La Ilustración Española y Americana, suplemento 32, 30 de agosto de 1908.

9 Salvador García Castañeda, "Treinta intensos años", Canciones de la guerra de la Independencia, recopiladas por Federico Olmeda, libro introductorio del DVD (Fundación Joaquín Díaz, Urueña, 2003, pp. 4-6). 
Además, quien desee hacerse una idea más académicamente filológica de la cuestión puede consultar el minucioso catálogo de Ana Freire sobre la Poesía popular durante la guerra de la Independencia española (1808-1814), que atiende tanto a las composiciones más tradicionalmente populares -las menos, por ciertocomo a las -muchísimas- de autor, aunque de tono a veces popularizante, que nacieron al calor de los hechos ${ }^{10}$.

Tras asomarnos, aunque haya sido tan a vuelapluma, a estas crónicas y apuntes decimonónicos sobre la francesada, dominados por el punto de vista personal, por la memoria directa o casi directa de los hechos, por el tinte progresivamente folclórico hacia el que va inclinándose lo que debió nacer como biografía o como historia, vamos a atender ya a ciertas memorias orales, a un puñado de documentos de carácter folclórico, que los siglos xx y XXI han guardado y retenido de aquellos hechos. Historia no of $i$ cial, anécdotas dispersas, vislumbres deshilvanados, pero dotados, justo por eso, y por lo asistemático, escurridizo y difícil de su localización y acopio documentales, de extraordinario valor.

Fijémonos, en primer lugar, en algunas de las canciones que acompañan las danzas de palos tradicionales hasta hoy en el pueblo de Almudévar, en la provincia de Huesca, donde los improperios antifranceses asoman entre muletillas rítmicas no del todo inteligibles:

Cuando el francés vino a España

llegó con grande traición, quería engañar a toda la nación.

Detente, mochu, detente, traidor, muera, muera, muera, muera Napoleón.

Cuando el francés vino a España, vino con grande traición, que sí, a engañarnos a toda la nación.

Lengua pulida de España vino de Francia un francés a aprender la lengua de una aragonesa,

10 Poesía popular durante la guerra de la Independencia española (1808-1814). Índice de las composiciones publicadas en la prensa periódica y en folletos de la "Colección Documental del Fraile", Grant \& Cutler, Valencia, 1993. 
a aprender la lengua de un aragonés.

Tres, tres, con la aragonesa, tres, tres, con el aragonés ${ }^{11}$.

He aquí otra canción, viva -en el seno, curiosamente, de un juego infantil- en pueblos de la provincia de Granada:

El agua viene turbia, quién la habrá enturbiado, los pícaros franceses, mamita mía, que estaban bañando sus caballos ${ }^{12}$.

"Un poco más confusa se nos presenta una letrilla que probablemente se haga eco de algún suceso de la guerra de La Independencia. Los portugueses, aliados de los españoles, debieron salir malparados", dice el editor de esta otra confusa y enigmática canción acompañante de una danza de palos de los pueblos de Almajano y Valdeavellano (Soria):

Ya se tiran, ya se matan, ya se hieren, ya se dan, los portugueses a gritos llorando piden la paz ${ }^{13}$.

11 Manuel Garrido Palacios, "La ronda, el dance, la justicia. Almudévar. Huesca”, Revista de Folklore, 237 (2000), pp. 86-87.

12 M.L. Escribano Pueo, T. Fuentes Vázquez, E. Gómez-Villalba Ballesteros, F. Morente Muñoz y A. Romero López, Juegos infantiles de tradición oral, Universidad, Granada, 1994, núm. 219B.

13 Véase Javier Asensio García, Helena Ortiz Viana y Fernando JALÓn JADRAQUE, "Las danzas procesionales de Cameros y el norte de Soria", Culturas Populares, 4 (2007), núm. 31; puede consultarse en la siguiente dirección: http://www.culturaspopulares.org/textos4/articulos/asensio.htm. El conflicto hispano-francés (¿la guerra de la Independencia de 1808-1814? ¿La guerra de Sucesión de 1702-1713?) al que alude este tipo de canciones no es fácil de identificar. He aquí otras estrofas registradas por los autores del artículo, vivas aún como letras de danza en pueblos diversos de La Rioja y de Soria: "El rey de España en campaña / y el de Francia en su retiro / y España será de Francia / el tiempo doy por testigo. / Muera el rey francés, / fuera el rey francés / por haber dado guerra / contra nuestro rey" (Viniegra de Arriba, La Rioja); "Al rey de España / han matado / la sangre ya correrá / las potencias se han opuesto / sabe Dios quién ganará. / Muera el rey francés, / muera el rey francés / porque ha puesto guerra / contra nuestro rey" (Santa Cruz de Yanguas, Soria); "Ya sale el rey a campaña / y el capitán general / y las tropas 
El caso de la tradición vasca resulta absolutamente sorprendente. En aquellas tierras, y en lengua vasca, ha sido documentado, desde mediados del siglo XIX hasta hoy, un repertorio extraordinariamente nutrido e interesante de canciones tradicionales, y también de canciones improvisadas (bertsos que cantan de repente los bertsolaris) acerca de la francesada, que fue vivida allí -justo en la frontera entre España y Francia- con dramática intensidad. A la labor descomunal del gran etnógrafo Antonio Zavala se debe el catálogo, el estudio y la edición de muchas de ellas, que han llenado dos volúmenes titulados Frantzesteko bertsoa-es decir, Estrofas de la francesada- que recogen una gran cantidad de versos, de los siglos xIx y $\mathrm{xx}^{14}$. Zavala ha publicado, además, algún ensayo en castellano que facilita el acceso a estrofas como las siguientes:

Hango anderek zabokaten konbertsazionia, desiratzen ere zuten gizon izatia:

"Frantzes porroxka horiek zertako debru dira?

Dozena baten aski ninduken bertze batekila".

La conversación que se traían las mujeres (era) que deseaban ser hombres:

"¿Para qué diablos sirven estos esmirriados franceses?

Acompañada de otra me atrevía contra una docena"15.

Mucho más trasparentes e inteligibles que las líricas precarias, casi vacías, sumamente deturpadas y desemantizadas, de las danzas de palos en castellano, aunque menos variadas y desarrolladas que la abundante lírica euskérica sobre la cuestión son las letras flamencas que todavía hoy, en la baja Andalucía, dejan oír los ecos de la resistencia que los gaditanos y sus paisanos de los pueblos del entorno opusieron al acoso y al dramático sitio de los franceses. Pericón de Cádiz (1901-1980), cultivador inmenso de los cantes de su Cádiz natal, nos legó recuerdos como éste:

españolas / salen para Portugal. / Ya se tiran, ya se matan / ya se rinden, ya se dan / los portugueses sangrientos / a voces piden la paz" (Almajano, Soria); "Ya viene el rey de Castilla / de capitán general / y las guardias españolas / se tiran a Portugal. / Ya se tiran, ya se matan / ya se rinden, ya se dan / los portugueses a gritos / llorando piden la paz" (Valdeavellano, Soria).

14 Los dos volúmenes fueron publicados dentro de la monumental colección Auspoa en 1991.

15 Zavala, "Estrofas en vascuence al 2 de mayo de 1808", en Auspoaren auspoa, t. 3: Itzaldiak/Conferencias, Sendoa, Oiartzun, 1999, p. 36 (el artículo fue originalmente publicado en la RDTP, 52, 1997, 255-260). 
...Y de fiesta, qué se yo las veces que habré estao de fiesta con Chiclanita... A mí me gustaba mucho su forma de cantar y le cogía cosas suyas pa luego hacerlas yo a mi manera. Me acuerdo que cantaba una romera con una letra que decía:

Baluarte invencible,

Isla de León,

donde se rindió el coloso

Napoleón Bonaparte

y allí perdió su victoria

y en Waterloo...

Y era un cante que yo no se lo escuchaba a nadie más que a él, lo mismo que la soleá-petenera, que tampoco la cantaba nadie. $\mathrm{Y}$, claro, a pesar de ser yo un chiquillo, me quedaba con aquellos detalles distintos de lo que se cantaba por aquel tiempo en Cádiz. Por eso siempre que tenía ocasión le preguntaba cosas de sus cantes, y él me decía:

-Mira, Pericón: si alguna vez yo falto, verás tú cómo vas a escuchar estos cantes y te van a gustar.

-Pero, José de mi corazón -le decía yo-, si yo t'escucho a ti cantar y sé que esos cantes no los hace nadie más que tú.

Y, efectivamente, cuando vine a Madrid y los grabé, Pepe el de la Matrona me lo dijo:

-Esos cantes no los ha cantao nadie más que Chiclanita ${ }^{16}$.

Mi amigo de El Puerto de Santa María, Luis Suárez Ávila, conocedor sabio y profundo de las tradiciones de su tierra, me comunica esta información de valor inapreciable acerca de los ecos que la francesada dejó en las letras del flamenco y en la memoria colectiva de su pueblo:

A la vista de Cádiz, El Puerto de Santa María fue una plaza ocupada por los franceses que la convirtieron en cuartel general de su caballería. El castillo portuense de Santa Catalina, en la costa, inutilizado desde la Guerra de Sucesión, no tenía posibilidades estratégicas. Cádiz fue bombardeada, desde sitios como el Trocadero, o desde el propio mar de la Bahía. En la Isla de León (San Fernando), los franceses no pudieron entrar, ya que el Capitán General Don Francisco Javier de Uriarte y Borja mandó desmontar y numerar las piedras del Puente de Zuazo.

José Chiclanita, cantaba por cantiñas ese hecho:

16 Las mil y una historias de Pericón de Cádiz, ed. J.L. Ortiz Nuevo, Sílex, S.L., 1990, pp. 145-146. 
Baluarte invencible

Isla de León, donde perdió su victoria

Napoleón, y en "Vaterló".

O la siguiriya gitana, todavía viva en la tradición oral, que cantaba Alonso, El del Cepillo:

No lo permitáis, no lo permitáis

que los franceses que están en la Isla se pasen a Cái.

Las coplas de alegrías cuentan la gran derrota de la caballería francesa, en la batalla del Cerro, cuando quiso apoderarse de Chiclana, y se mofaban del escaso poder de las bombas que disparaban contra Cádiz:

Diez mil franceses murieron en la Batalla del Cerro; pero han lograo un desquite: que una bomba mate a un perro.

A la presencia de la caballería francesa en El Puerto de Santa María, que ocupó como cuartel de su General, el Mariscal Soult, el Palacio del Marqués de Villarreal y Purullena, los conventos de la Victoria y el del Espíritu Santo, dejó en esta zona una serie de secuelas muy señaladas: el destrozo de gran parte de nuestro patrimonio histórico artístico. La soldadesca, por ejemplo, hizo una hoguera con las veinticinco tablas góticas, del pintor Juan Ramírez, el que introdujo a Esturmio en los ambientes artísticos andaluces, que estuvieron en el retablo primitivo de la Iglesia Mayor Prioral y se depositaron en el convento de Sancti Spiritus.

Pero, por el contrario, dejaron abandonadas numerosas sillas dragonas, de faldones cuadrados y dos conchas, de cincha ancha de librillo de tres hojas, abrochada con latiguillos, muy aptas para la doma, que todavía hoy existen en muchos guadarneses de El Puerto. Con ellas se usa pecho petral y, a algunas, en las acciones, se le han adaptado estribos vaqueros.

Los que no saben su origen, la llaman montura potrera. Recuerdo, al menos, cinco. Entre ellas una de mi propiedad, que presté a un amigo mío, llamado Francisco Caballero Pulido y se la robaron; otra en casa de Fernando Terry Galarza, y aun otras tres: una de mi suegro, Francisco Lena Pacheco, otra de un viejo labrador portuense, llamado Paco Galán, y otra de mi primo Eustasio Torreci- 
llas. Con "Didaco", un caballo tordo que tuve, me fotografié en la montura dragona el año 1976, con mi hija Ana en brazos.

Aún puede consignarse una herencia francesa más, en el traje bajoandaluz de montar: el marsellés, especie de chaquetón corto, de abrigo, que adquiría el populacho a los ropavejeros procedente de los abandonados o arrebatados al Regimiento de Marsella. Es el dormán, prenda turca, adoptada por todos los ejércitos europeos. El dormán, de paño, con multitud de adornos de pasamanería, ostentaba las insignias de los cuerpos militares y los galones y estrellas de las graduaciones. Desprovistos de todos esos añadidos, la gente del camino y los de a caballo, lo fueron adoptando y se convirtió, con el tiempo, en prenda de abrigo del traje corto de montar que se usa hasta hoy en día.

Por lo general era de paño, con algunos bordados y, sobre todo, con parches también de paño de diferente color, y pasamanería en las bocamangas, en los codos, en la espalda, en solapas y cuello o en las puntas. A veces tenía ricos bordados, bien de flores, bien de escenas andaluzas. Es el caso del marsellés de Antonio El Planeta, cantaor gaditano, estante en Triana, por los años 1830 y pico, que describe luego, en 1845, Estébanez Calderón:

"Un marsellés rico, con mangas primorosamente bordadas y golpes de sedería en lugar correspondiente, cobijaba sus brazos y espaldas, dejando ver por los remates de todo el ruedo, caídas, solapas y cuello, la ancha faja de pasamanería, en donde resaltaban en esmerada labor y prolijo dibujo de sedas de varios y vivos matices, todos los encuentros, grupos, lances y suertes de una corrida real de toros, desde el enchiqueramiento de las fieras hasta el trance del cachetín y el arrastradero de las mulillas y caleserillos. El marsellés era, en verdad, lo que nosotros los hombres llamamos una prenda del rey".

Yo poseo un marsellés, de mediados del xıx, de paño marrón, bordado en seda con flores y botonadura de plata, que tengo en una vitrina como una pieza digna de museo.

A los franceses, por aquí abajo, se les tenía, cuando yo era pequeño, gran odio. Quedaba viva en la memoria que, para evitar la rapiña y el expolio de sus tropas, hubo que fundir la plata de muchos vasos sagrados, frontales de altar e incluso templetes. Los franceses desmontaron de la Prioral el magnífico retablo de plata mejicana, obra de Don José Medina, que regaló el capitán portuense Don Juan Camacho Jaina, primer editor de Sor Juana Inés de la Cruz, pero el pueblo impidió que se lo llevaran ${ }^{17}$. 2007

17 Información facilitada por Luis Suárez Ávila, el 30 de agosto de 
Asombra apreciar hasta qué punto el cancionero flamenco andaluz quedó impregnado -hasta hoy- de memorias y de cantares sobre la francesada:

Incluso la jota, por mediación de algún patriota aragonés aficionado al canto, se personó en el ámbito de las cantiñas, y despojándose de solemnidades, se convirtió en otra forma nueva de expresar la alegría de aquel victorioso Cádiz:

Navarrico, navarrico, qué bien te sienta la gorra, ¿de qué regimiento eres? -¡De Navarra soy, señora!

Pregúntale a Zaragoza lo que Zaragoza sabe: con un puñao de valientes hicieron en Zaragoza retroceder a los franceses.

Una lancha cañonera por el río abajo va, y su mejor marinera es la Virgen del Pilar.

Alegrías que quedaron fijadas en el tiempo y en la memoria de los flamencos, renovadores incluso del repertorio, que extendieron por el siglo xix, y también el xx, con nuevas letras, aportaciones al recuerdo de aquellos días gloriosos:
Al marcharse los franceses una bala me encontré; llorando estaba la pobre porque no mató a un francés.
Murió amaneciendo el día, mártir de la patria era, muerte dieron los franceses a Lola la Piconera.
Qué desgraciaíto fuistes, barrio de Santa María, un barrio con tanta gracia, qué de bombas recibistes. 
Y cada pueblo tiene su orgullo, pero Cádiz lo supera, fue la única de España que no arrió su bandera ${ }^{18}$.

Si del terreno de la lírica pasamos al de la prosa, no será difícil apreciar cómo, en muchos pueblos de España, siguen conservando recuerdos, dramáticos aunque velados sin duda por los tintes de la ficción, del paso de los franceses. En Manzanares (Ciudad Real) por ejemplo:

El milagro de mi pueblo, ése ya fue del santo, que es la historia que cuentan allí. Dicen que... Además que, por lo visto, sí que es cierto, porque tengo aquí las pruebas. Este santo es Jesús del Perdón.

Pues en la época que estuvieron los franceses en España, llegaron al pueblo, violaron a todas las mujeres mientras los hombres estaban en el campo. Hicieron todo lo que querían, y fueron a quemar la iglesia. Entonces el capitán que iba al mando de todos estos franceses entró a la iglesia, y empezaron a destrozar todos los retablos, y lo único que les quedaba era el santo. Entonces él mismo, con un hacha, intentó destruir la imagen, y entonces parece ser que se clavó un clavo en la mano.

Entonces a él le sorprendió muchísimo, y no sé qué le ocurrió, que como no podía coger el hacha, porque tenía un dolor muy grande, pues se quedó mirándole al santo, se arrodilló, empezó a llorar, y le pidió perdón, y le dejó al santo el fajín y el bastón de mando. Se lo dejó y se marcharon del pueblo. Y todavía está allí19.

Leyendas de este tipo, acerca de imágenes milagrosamente salvadas de la barbarie francesa, las hay en muchos otros pueblos y ciudades de España. Por ejemplo, en Zamora, donde de la virgen del Canto, tenida allí por muy milagrosa, se cuenta que

en el siglo XIX, a raíz de la invasión de las tropas francesas, quedó la ermita convertida en una fábrica de harinas, y, a pesar de que todas las reliquias y objetos de culto fueron profanados y robados, la imagen no fue tocada porque con el polvo de la harina fue

18 José Luis Ortiz Nuevo, Pensamiento político en el cante flamenco. (Antología de textos desde los orígenes a 1936), Biblioteca de la Cultura Andaluza, Sevilla, 1985, pp. 75-77. Véanse más canciones y comentarios de este tipo en pp. 68-78.

19 Entrevista realizada por Rafaela Nieves a Pedro Díaz, de Manzanares (Ciudad Real) en 2000. 
adquiriendo un tono blancuzco que hizo posible que se confundiera con la pared.

En 1812 fue llevada secretamente por un harinero que descargaba costales en uno vacío hasta el monasterio del Sancti Spiritus de las dominicas, pues estaba apilando los sacos, cuando le pareció ver cómo una mano se movía en una hornacina, y al acercarse descubrió la sagrada imagen.

En 1822, el 10 de septiembre, tras la reconstrucción de la ermita, fue trasladada de nuevo en magna procesión hasta la misma ${ }^{20}$.

En la Villa de Don Fadrique (Toledo) y en Sigüenza (Guadalajara) sigue viva, y de esta manera, la memoria de los desmanes cometidos por los invasores franceses:

Mi bisabuela Josefa Medina, natural de Socuéllamos, residente en Villa de Don Fadrique (Toledo) y nacida hacia 1874, contaba a sus hijos, y sus hijos contaron a sus hijos algunos hechos sucedidos cuando llegaron los franceses. A mí me lo han contado dos de sus nietas, Josefa Muñoz Huertas, nacida el 26 de marzo de 1925. Durante la Guerra de la Independencia, un lugareño se colocaba en la torre de la iglesia de vigía. Cuando llegaban los franceses tocaban las campanas para avisar a todos los del pueblo. Se refugiaban en una cueva muy grande que había en una parte del pueblo, muy cerca de la casa de mi familia. Esa cueva ya no existe, al menos la entrada ya ha desaparecido. Otra de sus nietas y hermana mayor de Josefa, Inmaculada Muñoz Huertas, nacida el 11 de marzo de 1921, recuerda también que su abuela le contaba que la gente se escondía cuando llegaban los franceses en una especie de túnel muy ancho que había debajo de una calle. También recuerda que las mujeres tenían preparadas las sartenes con aceite hirviendo para tirárselo a los franceses a la cabeza.

Cerca de Sigüenza (Guadalajara) hay un rebollar y se cuenta que por allí estuvo El Empecinado, uno de los guerrilleros que se enfrentaron a los franceses.

Ese rebollar une Sigüenza con Pelegrina, pueblecito situado en una colina coronada por un castillo que fue residencia de verano durante mucho tiempo del Obispo de Sigüenza. Tiene ahora su castillo en ruinas. Se cuenta que los franceses lo volaron. La

20 Concha Ventura Crespo y Florián Ferrero Ferrero, "La Virgen del Canto", Leyendas zamoranas, Semuret, Zamora, 2001, p. 113. Véase también lo siguiente: "Y en esos cuatro siglos siempre ha permanecido presidiendo el altar la imagen del bendito Cristo de Morales, salvo entre los años 1811 y 1819 en que, por los muchos daños que produjeron en ella los franceses, fue preciso trasladarle a la parroquia del vecino pueblo, hasta que se llevó a cabo la restauración” (id.). 
colina en la que está el pueblo de Pelegrina se encuentra un valle regado por el río Dulce.

Para llegar a Pelegrina andando desde Sigüenza (unos 9 km) hay que vadear un poco el rebollar y seguir una antigua calzada romana por la parte alta de la montaña. Después hay un cortado, hay que bajar la montaña para llegar al valle. En el cortado, cuando llueve, hay una cascada. Los lugareños cuentan que se despeñó por ahí un capitán francés con caballo y todo.

En la Catedral de Sigüenza, todavía el guía habla de los tesoros que se llevaron los franceses, en especial, reliquias de santos. Habla de la profanación de los relicarios ${ }^{21}$.

Interesantísimas son las trazas que la francesada dejó en la toponimia española, y también en la portuguesa. En el pueblo burgalés de Mozuelos de Sedano hay, por ejemplo, una Cueva del Francés de la que se cuenta lo que sigue:

Y bueno, pues ahí enfrente había otra que la llamaban la Cueva del Francés, que se conoce que eso era de cuando vinieron los franceses, y yo no sé si se escondieron allí. Todo esto me lo contaba mi padre, me contaba bastantes historias... Y cómo apareció un francés muerto en un camino, más para allá, y que hubo un señor, y dijo -era un señor bisabuelo de un vecino de aquí-, y dijo:

-Uy, pues voy a mirarle cómo tiene las tripas.

$Y$ resulta y dice:

-¡Pues si las tenía igual que las de un cerdo!²2.

En otro pueblo burgalés, Quintanilla de Sotoscueva, quedó esta otra asociación toponímica ligada a los invasores franceses: "En el prao del Picadero domaban los caballos los franceses; por eso le llaman así”23. Un capítulo muy interesante, al que no podemos dar mayor espacio aquí, de las leyendas sobre los de 2007.

21 Julia Sevilla Muñoz me comunicó estos recuerdos el 31 de agosto

22 Leyenda recogida por Elías Rubio Marcos y José Manuel Pedrosa en Mozuelos de Sedano, el 6 de agosto de 1997, ed. en José Manuel Pedrosa, César Javier Palacios y Elías Rubio Marcos, Héroes, santos, moros y brujas (leyendas épicas, históricas y mágicas de la tradición oral de Burgos). Poética, comparatismo y etnotextos, Tentenublo, Burgos, 2001, núm. 201.

23 Leyenda recogida por Elías Rubio Marcos en Quintanilla de Sotoscueva en julio de 1997, ed. en Héroes, santos, moros y brujas..., núm. 202. En el mismo libro podrán encontrarse unas cuantas leyendas antifrancesas más: núms. 195-203. 
invasores napoleónicos, es el de los etnotextos portugueses. He aquí este único pero muy interesante ejemplo, que reviste la forma de auténtica leyenda etiológica o de fundación:

Durante las invasiones napoleónicas, un regimiento de soldados franceses pasó por una pequeña aldea. Uno de los soldados tenía sed y pidió un poco de agua a una muchacha de la cual quiso saber el nombre: Ana. Cuando se fue, le dirigió la palabra diciendo:

\section{-Merci, Ana.}

Esa pequeña aldea, por donde pasó el regimiento napoleónico, pasó a tener el nombre de Merceana, debido a la frase del soldado francés ${ }^{24}$.

En el pueblo de Pontesampaio (Pontevedra) aún quedan rescoldos de recuerdos de la francesada, que mezclan el ingrediente realista con elementos de ficción tan insólitos como el supuesto "cañón de madera" con el que los patriotas gallegos se enfrentaron al invasor:

En mi pueblo, Pontesampaio, a unos kilómetros de Pontevedra, hubo una batalla de la que los gallegos están bastante orgullosos. En Pontevedra, enfrente del Ayuntamiento, hay un monumento a los héroes de Pontesampaio. La gente del pueblo se enfrentó a los franceses con un cañón de madera, y los venció.

Mi padre dice que muchas veces, cuando usaban el arado en su finca, aparecían balas de cañón redondas. Las colocaban en la escuela, pero fueron desapareciendo. La gente también se las llevaba a sus casas. La bisabuela de mi padre decía que los primeros zapatos que ella tuvo se los hicieron con la mochila de un soldado francés. Eran de cuero ${ }^{25}$.

Más ecos de la francesada, aunque ahora cómicos: un chiste contado en la provincia de Castellón:

Me lo contaron cuando era muy pequeñito, y no recuerdo dónde. Seguramente sería en Castellón, donde yo vivía, y donde tengo mis amigos. Si no, por aquella época, no podría ser otro sitio excepto Sant Mateu, el pueblo de mis padres, y que también está en la provincia de Castellón.

24 Traduzco de Isabel Morgado, Viagens ao Imaginário, Centro de Formaçao das Escolas, Torres Vedras, 1999, p. 34.

25 Rosa Vidal, de 27 años, entrevistada por mí en Manchester (Gran Bretaña) el 7 de septiembre de 2003. 
Bueno, te cuento el chiste; intentaré recordar lo mejor que pueda la versión original.

Esto eran los catalanes contra los franceses en unas montañas, y estaban todos allí, escondidos detrás de las piedras, para que no les dispararan. Hasta que un día dice un catalán:

-Oye, ¿los franceses no se llaman todos "François"?

- Sí.

-Pues diremos “FFrançois!”. Y ellos dirán "¿cuá?”. Y nosotros “ipum!”, les disparamos. Y “¡François!”, “¿cuá?”, y “ipum!”. Y así iremos haciendo...

Los catalanes se quedan escondidos hasta que uno dice:

-“¡François!”.

Y un francés:

-“Cuá?”.

-“"Pum!”.

-“¡Bieeeeennnn!”

-“FFrançois!”.

-“¿Cuá?”.

-“Pum!”.

-“¡François!”.

-“¿Cuá?”.

-“Pum!”.

Hasta que los franceses se dan cuenta del truco y dicen:

-Oye, ¿los catalanes no se llaman todos "Jordi"?

-Ouí.

-Pues diremos “Jordi”. Y ellos dirán “¿qué?”. Y ¡pum!, les dispararemos.

-iMuy bien, muy bien!

Y entonces van los franceses y dicen:

-“iJordi!".

-“¿Qué? ¿Eres François?”

-“Cuá?”.

-“Pum!”.

Cuando se cuenta, al decir "pum" se hace un gesto como si disparases un fusil. Le da más gracia. Te he escrito lo de los franceses como se pronuncia, que queda más "oral" 26 .

No han sido raras, en la tradición folclórica española, oraciones burlescas y paródicas que hacen burla y escarnio de los franceses. Algunas extensas y deslumbrantes, como los llamados "padrenuestros de Soult" o "los mandamientos de los franceses", que por limitaciones de espacio no podemos reproducir

26 Alfonso Boix Jovaní, de 32 años, que vive en Castellón desde muy niño, me comunicó este chiste el 22 de junio de 2007. 
aquí. Consignaremos, en cambio, este ejemplo mucho más raro, con los curiosos comentarios de su editor:

Falsa a todas luces, pues, es esta coplita burlesca:

$$
\begin{aligned}
& \text { A cada Santo, } \\
& \text { su padrenuestro, } \\
& \text { pero a San Roque, } \\
& \text { ná más que medio, } \\
& \text { que pa Santo francés, } \\
& \text { bastante es... }
\end{aligned}
$$

Copla que quizá naciera en alguna francesada, dejándose llevar el pueblo por la pasión que, por noble que sea, nunca debe afectar a lo religioso ${ }^{27}$.

Y concluiremos este recorrido tras las huellas dejadas por los invasores franceses y por sus andanzas peninsulares en el imaginario colectivo de nuestro país, con otra curiosidad: el relato, a mitad de camino entre lo trágico y lo cómico, que el ilustre hispanista Jeremy Lawrance me confió en Manchester, en 2003:

Un antepasado de mi familia fue un general que se llamaba Norcliffe Norcliffe. En mi familia se cuenta que, durante la batalla de Arapiles, estaba montado en un caballo cerca de Wellington. Y una bala se le llevó la pierna, y también otras partes, por lo que ya no pudo tener descendencia. Cuando la bala le destrozó la pierna, dijo a Wellington:

-Sir, I believe that they have shot my leg off.

Y Wellington le miró y dijo:

-I believe they have so.

Cuando yo visité Salamanca siendo joven, mi padre me dijo en broma que reclamase la pierna, porque nunca la habían devuelto ${ }^{28}$.

La variedad de registros, de enfoques, de matices que ofrecen los etnotextos y los documentos que hemos ido desgranando permiten sumar a la historia grande de la francesada, la intrahistoria de la memoria local, de la evocación familiar, de las tradiciones privadas -o de lo que va quedando de ellas. Cubier-

27 A. Castillo de LuCas, Folklore médico-religioso: hagiografías paramédicas, Morata, Madrid, 1943, p. 54.

28 Jeremy Lawrance, entrevistado por mí, en Manchester, el 7 de septiembre de 2003. 
tas, siempre, de la inevitable pátina de ficción que el paso del tiempo va depositando sobre todo aquello que se hace con la materia del recuerdo.

Sobre esta polifonía de voces cada vez más borrosas y más desconcertadas -desconcertadas porque son cada vez más tenues, porque cuando menos se espera se dejan oír por aquí y por allá, en los lugares en que la memoria caprichosa decide resistir con más empeño- es posible que no pueda hacerse una historia positiva de hechos, de nombres y de fechas. Pero, a cambio, sí puede alcanzarse algo que tampoco carece de importancia: una crónica del modo en que las grandezas y las miserias de la guerra de la Independencia han seguido, de algún modo, vivas entre nosotros ${ }^{29}$.

José Manuel Pedrosa

Universidad de Alcalá

29 Varios amigos me han hecho indicaciones sumamente agudas y útiles acerca de este artículo, y proporcionado materiales muy valiosos: Mario Hernández, Julia Sevilla, Luis Suárez Ávila, Josemi Lorenzo, José Luis Garrosa, Carina Zubillaga. Gracias a todos ellos. 